\title{
APPROACHES TO EMPLOYEE DEVELOPMENT IN CZECH ORGANISATIONS
}

\author{
Lucie Vnoučková ${ }^{1}$, Hana Urbancová ${ }^{2}$, Helena Smolová ${ }^{1}$ \\ ${ }^{1}$ University of Economics and Management, ${ }^{2}$ Czech University of Life Sciences Prague
}

\begin{abstract}
Highlights
- $\quad$ Research outcomes identified types of employee development programmes of organisational learning

- $\quad$ Approaches to employee development in Czech organisations are described
\end{abstract}

Education, development, knowledge management, career development and talent management are currently often discussed themes regarding strategic management of organisations. Those concepts are strategically important. Therefore the aim of the article is to evaluate possibilities of employee education and development and identifies main approaches to employee development in Czech organizations. The results are based on a quantitative survey by questionnaire data collection. The results shows that $70 \%$ of respondents have possibility of development; $86 \%$ uses their skills and abilities and $63 \%$ stated that their employer support their development. On the contrary, $27 \%$ do not feel any possibility to grow and that may lead to disaffection, loss of production or even to employee turnover. Based on the results of the analysis, employees, who miss adequate level of development are usually key and knowledge employees; it is necessary to support their career plans and development to retain them in organisation.

\author{
Article type \\ Full research paper \\ Article history \\ Received: February 28, 2015 \\ Received in revised form: March 15, 2015 \\ Accepted: March 26, 2015 \\ Available on-line: March 31, 2015
}

\section{Keywords}

Development, education, learning, organisations, concepts

Vnoučková L., Urbancová H. and Smolová H. (2015) “Approaches to Employee Development in Czech Organisations”, Journal on Efficiency and Responsibility in Education and Science, Vol. 8, No. 1, pp. 1-7, online ISSN 1803-1617, printed ISSN 2336-2375, doi: 10.7160/eriesj.2015.080101.

\section{Introduction}

Constant change in the external environment and the implementation of new trends in business requires that organizations adapt to new conditions, and that they respond to them appropriately. Human Resources Management is one of the most complex and most important areas on which an organisation must focus (Thomson, 2007). Successful organizations therefore have one common factor: quality employees. For an organization it is important to acquire and retain talented employees who can become a key competitive advantage Talent is often defined as natural ability to do something well, and Hroník (2007) adds that at present the criteria for talent are respect, productivity, and perspective - not age, as was thought previously. Each organization may have its own criteria when selecting talent according to which talent is sought and identified (Morongová, Urbancová, 2014). Talent management may be considered as a proper tool for applying and retaining talented employees, and which consists of three activities, the recruitment, development, and retention of these workers, and yet it is necessary that they are motivated to work, that they consider their work stimulating and interesting, that they may have and feeling of personal success and, last but not least, that they may find in it an opportunity for personal development. All of these factors and many others influence the resulting loyalty of the worker to the organization in which they work.

This article aims to evaluate possibilities of employee education and development and identifies main approaches to employee development in Czech organizations. The paper is composed of five sections. The first is Introduction, the second one is
Theoretical Background, this followed by a presentation of the methodological approach. Subsequently, an analysis and discussion section comes before the recommendations. Finally, authors conclude the paper and summarize the contributions and limitations of the article.

\section{Theoretical Background}

According to probably one of the most commonly cited definitions, human resources management may be characterised as strategically and logically engineered approach which serves for the management of an organization's most valuable asset - its people (Armstrong, 2007, p. 27). Employee development can also be defined as "development of the qualitative aspects of the interorganizational work force." (Dvořáková, 2004, p. 106), whereas this change may applies for example to qualifications, personal potential, capability, as well as health or lifestyle (Bělohlávek, 2008).

It is possible to include employee safety (future certainty and also safety on workplace), compensation, management of mutual relationships and employee development. This is one of the most important functions of human resources management (Hameed and Waheed, 2011). From the results of numerous studies it can be concluded that practices applied as part of human resources management significantly influence the behaviour and attitudes of employees (Muse and Stamper, 2007; Edgar and Geare, 2005). Employee development should therefore be part of the overall strategy of an organization (or its policies) (Kocianová, 2010, p. 169; Drucker, 2000), as over the long term it can be 
considered an indisputable competitive advantage (Stýblo, 2008 , p. 81). For this reason nowadays in particular and number of companies focus on employee development with a certainly regular periodicity (Useem, 1993; Kavita and Diksha, 2014).

In association with the issues under analysis it is also important to specify certain differing terms:

- Development - achieving the desired changes through learning. This is more generally focussed, and takes as its goal the "training" of the employee with variable knowledge, skills, and attitudes that can later be used in his personal growth (Bedrnová, Nový and Jarošová, 2012, p. 192).

- Learning - the process of change. An active practice of the trainee that consists of the quantitative and qualitative growth of adopted knowledge, but also the transfer and potential changes of values, attitudes, interests, and other elements focussed on human development (Veteška and Tureckiová, 2008).

- Education - one of the methods of learning and process of acquiring and adopting knowledge from various spheres of human awareness (Vodák and Kucharčíková, 2011).

Employee education, learning, and development, according to Bedrnová and Nový (2007), occupy and significant and essential place in the personnel management of each organization. Its objective is to employ technically skilled employees at all levels who take initiative and are flexible with regard to managing the demands of and given position.

Dvořáková et al. (2007) and Koubek (2007) agree that employee development is more focused on the current position than on employee professional potential, future, and career.

Kociánová (2010), Koubek (2007), Vodák and Kucharčíková, (2011) present the opinion that organizations are nowadays exposed to a range of external influences and situations that result in the necessity to adapt the capabilities of workers to changing conditions in their positions. Of course, Robbins et al. (2003) demonstrate that many employers nonetheless oppose educational and developmental activities as they assume that either academic institutions or the employees themselves should be responsible for technical/professional preparation. From the results of the study by Vnoučková (2014) it can be determined that within the Czech Republic in general, organizations support employee education and development, but the initiative should not be missed on the part of the employee. This issue is further specified by Constantine (2012), who states that while longterm development remains the responsibility of the given employee, the organization is fully responsible for professional development. According to this author employees may be accepted with a certain set of skills, knowledge, and capabilities, but at the moment the role and responsibilities of the given position change, the company has a social responsibility to invest into its human capital. As part of the analysis carried out by the company PPM factum (2012) among employees of regional governments it was determined, for example, that a mere $18 \%$ of respondents Strongly Agree with the statement that they have enough opportunities for constant expansion of their knowledge and skills. $60 \%$ of the respondents Somewhat Agree and 22\% Do Not Agree.

Tureckiová (2004, p. 89) considers company education as the main tool applied in employee development. They define this as improvement, expansion, deepening and or change to the structure and content of the professional competency of the employee, which contributes to the aforementioned increased productivity of individuals and the company as a whole.

According to Armstrong (2007, p. 509) employee development consists of allowing employees not only to develop and learn, but also to engage in diverse educational events, and a critical attribute is also planning, execution, and assessment of educational and development programs.

As far as the employee development programs mentioned are concerned, the majority include various training techniques, plans, and a learning environment which helps employees to improve their skills and later apply them in their work (Gerbman, 2000). Of course, according to Koubek (2007) nowadays traditional methods of employee education are no longer sufficient. Much more often they consist of "developmental activities focused on forming a broader base of knowledge and skills than that currently required by the position and not least the formation of the employee personality, the formation of their value orientation, the adaptation of their culture to the culture of the organization" (Koubek, 2007, p. 252). Thanks to these development activities the flexibility of the employee is formed, as well as their preparedness for change.

Lee and Bruvold (2003) determined that company investments in employee education and development contributes to positive employee perceptions of the organization. It can be deduced from studies by Schmidt (2007) that employees in general appreciate options for development, education, or training and consider them an essential component of their work.

Moreover, Champathes (2006), Antonacopoulou (2000), Nel et al. (2004), Lee and Bruvold (2003) see a very close link between development of employees and their productivity. With development the professional satisfaction of employees increases (Edgar and Geare, 2005; Georgellis and Lange, 2007), they are more devoted to their work and as a result their performance improves as well. This is confirmed by Dvořáková et al. (2007), who evaluate investments in people (via their development0 in the form of systemic improvement not merely of individual performance but also of team and company performance. An employee may therefore at the present be considered as a wealth of the company, an asset or a human capital, whereas investments in them consist of the very opportunities for education and development (Armstrong, 2005, p. 27).

Indeed, increased satisfaction, motivation, engagement, and loyalty may bring an organization a number of advantages. Tureckiová (2004), Dvoráková et al. (2007) cite the following, for example: the overall improvement of the company image, better applicability of employees on the job market, or improvement of employee quality of life. Nel et al. (2004) add, for example, positive changes in employee behaviour, ability to advance, minimum need of supervision, or reduction in turnover. Nor can be overlooked, of course, certain pitfall associated with employee development. Among them the authors particularly rank costs associated with employment and increased risk of employee defection to the competition due to their increased value on the job market.

Lipman (2013) sees a basic problem associated with employee development overall in ignoring this valuable activity or in the fact that many companies consider it merely a bureaucratic necessity. Companies can subsequently pay the highest tax key/talented employees.

As part of issues of employee development it is also important o specify the term self-development. Folwarczná (2010) defines it as striving for continuous self-refinement, which emphasises the importance of lifelong learning. The primary responsibility 
for the process of learning in this case is transferred directly to the individual doing the learning. Deibl (2005) adds that self-development serves primarily for enriching the person themselves, consisting of a tendency to do everything the individual perceives as within his/her capabilities.

According to Folwarczná (2010, p. 77) the existence of efforts for self-development of course depend on several basic assumptions. Among them are a company culture that supports self-development, the interest and support not only of employees but of the leadership themselves, and the willingness of managing employees to change to change the manner of their work as part of their responsibilities. An option to enable developing individuals to continue working on non-standard projects even after the completion of the self-development program plays a role as well.

As noted by Vodák and Kucharčíková (2011), of course, selfdevelopment should in no way operate without the critical attribute of motivation. A willingness to improve is a very significant element of any educational process as it is motivation which to an undeniable extent influences the effectiveness of learning and development. Motivation therefore generally helps organizations create an encouraging work environment and situations in which employees can apply their skills and capabilities (Armstrong, 2007).

Motivation may also be divided according to Armstrong (2009) and Kociánová (2010) into internal and external motivation. The authors include as external motivation both compensation (increased salary, praise, acknowledgement and recognition, promotion), and punishment (disciplinary proceedings, docking pay, criticism). On the contrary, inner motivation is composed for example of the aforementioned opportunity to apply and develop ones skills and capabilities, but also the prospect of interesting and stimulating work, freedom to act or the opportunity to functional progress and personal success. Osborne (2002) afterward designates meaning, importance, and the utility of work performed as the primary determinants of professional satisfaction.

Furthermore Stýblo (2013) identifies certain cross-sectional trends that pertain to successful people motivation. Among them he includes more effective work with employee benefits, support of independence, willingness to assume rights and responsibilities for work performed, better and more effective use of employee potential, and creation of space for their engagement.

Malátek (2011) presents the opinion, given no company in interested in having their products and services out-dated, that the systematic development of employees is therefore required. On the other hand, employees welcome development especially because they can use it to satisfy their social and psychological needs (e.g. self-actualization, growth on the social ladder, etc.). For these reasons a number of organizations therefore offer their employees so-called supplemental development, which is not dependent on the requirements of the given work position. Veber (2005) adds that surveys indicate that apart from increasing their professional standard, the option of development and increased qualifications acts as a very strong element associated with motivation for work, employee stability, and the creation of good relationship to work in general.

On the basis of the information stated it is therefore possible in conclusion to agree with Armstrong (2007) that the general goal of employee development is to ensure that the organization has employees of the quality it needs to achieve its goals. This is possible to achieve only once employees acquire the knowledge and skills necessary for the effective performance of their work and its continuous improvement, which will ultimately maximise their potential for growth.

\section{Materials and Methods}

The data were mainly extracted from secondary sources and our analysis and discussion is linked to outcome synthesis and the evaluation of international research results and the results come from primary survey.

The survey was carried out using employees. The employee data set comprised 125 employees. The employees were employed full time. Most employees, $82 \%$, have other than managerial positions. They are rank-and-file employees and $70 \%$ have no university education.

The employee respondents were structured as follows:

- employee age category: $11 \%$ - 20 to 24 years, $32 \%-25$ to 30 years, $35 \%-31$ to 40 years, $20 \%-41$ to 50 years and $2 \%$ over 51 years;

- employee professional experience: $10 \%$ - less than 1 year, $36 \%$ - more than 1 year and up to 5 years, $26 \%$ - more than 5 years but less than 10 years and $28 \%$ more than 10 years;

- employees work in the following industries: $1 \%$ primary sector, $18 \%$ secondary, $81 \%$ tertiary;

- employees work for organizations of size: $26 \%$ small, $29 \%$ medium, 45\% large organizations;

- employees work for organizations owned by: 74\% Czech organizations, 7\% Czech organizations with a foreign owner, 19\% multinational organizations.

The data collection instrument included questions to measure the activities of learning and development support in organisation. The questions were designed based on theories (see theoretical background) and similar researches driven by Colvin (2010), Gannon and Maher (2012), Michela (2007) and Vronský (2012).

Respondents' reactions to target statements and their attitudes to the given matter were restricted by offering a set of several statements. The extremes of the seven-point scale represented bipolar concepts of the evaluation dimension. All the questions were measured in a Likert type scale with verbal anchors in 1 (strongly agree) and 7 (strongly disagree) or, provided it was not possible to favour either of the sides, selected a median, neutral value (the median value was characterized by number 4). The scale permitted not only the specification of respondents' attitudes, but also their intensity.

The data were evaluated using the tools of descriptive statistics and the methods of comparison, induction, deduction, and synthesis. Descriptive statistics used to test the results included absolute and relative frequency, correlation analysis. Further analyses were based on multidimensional statistical methods factor analysis (Varimax rotation; the Kaiser-Guttman rule was applied to select a group of significant factors. Following the recommendations of Anderson (2009), only determinants with an absolute value exceeding 0.3 were selected as significant for factor development; positive and negative dependency was further analysed in relation to its final benefits).

To evaluate the data IBM SPSS Statistic Data Editor, version 22 and MS Excel was used.

\section{Results and Discussion}

Results have indicated that a total of $43.2 \%$ of employees tend toward the opinion that the organization in which they work 
is devoted to the development of talented employees. It can therefore be expected in the current competitive environment and increasing globalization that more and more organizations will focus on the development of talented employees. Given the results of analyses, practice, and the demographic evolution of the populace it can be stated that the number of talented individuals in the population is relatively limited. For this reason the area of development of current employees is an increasing interest of organizations in that it allows them to increase the competitiveness through effective use of the potential of individual employees.

And yet every employee has a different view of the opportunity to develop his knowledge, capabilities, and skills. One group of employees prefers expanding rights and responsibilities, another enhancement of work or participation in training courses or involvement in talent programs, for example. Every organization should offer each talented employee the option to develop their strong points, improve their individual overall performance within their individual competencies, strengthen their motivation, and enable their career development.

For this reason, respondents in this study from the ranks of employees in organizations were asked whether they have the opportunity to develop their competencies in the organizations where they work and how they perceive their own development. How the individual employees perceive this opportunity for development was determined using the Likert scale 1-7 (1- strongly agree and 7-strongly disagree) for 12 selected assumptions (A through L, see table 1), which were based on theoretical perspectives of work.

\begin{tabular}{|l|c|}
\hline Statement & Mark \\
\hline I have enough possibilities to ongoing development & A \\
\hline I use my skills and abilities on regular basis on my job position & B \\
\hline My job is inspiring and interesting & C \\
\hline My job gives me feeling of personal success & D \\
\hline My job is beneficial and valuable & E \\
\hline I take responsibility without any problem for my job tasks & F \\
\hline Organisation support my development & G \\
\hline Possible learning and development motivates me & H \\
\hline $\begin{array}{l}\text { Organisation offer possibility of awards for outstanding work out- } \\
\text { comes }\end{array}$ & $\mathrm{I}$ \\
\hline Development affects my work performance & J \\
\hline I participate on my development regularly & K \\
\hline Development and education is part of my job & L \\
\hline
\end{tabular}

Tab. 1: Statement of respondents

The results in table 2 present the relative frequency of answers from the individual employees in the individual tested assumption. On the basis of the results assessment it can be said that the majority of respondents $(33.6 \%)$ inclined toward answering that they Somewhat Agree that they have enough opportunities for constant expansion of their skills. A total of $73.6 \%$ of respondents ranked these opportunities positively. Only $4 \%$ of those addressed stated that they have no opportunities for development.

More than $34 \%$ of the respondents stated that they entirely agree that they are able to make use of their abilities and skills in their work, this trend is also positive as it can be stated that $86.4 \%$ of the respondents tended toward a positive response, with merely $10.4 \%$ of those addressed inclining to answer that they do not have any opportunity to use their skills and capabilities in their work to any great extent. A mere $3.2 \%$ of respondents responded neutrally.

It can also be said that most of the respondents (35.2\%) entirely agree that for them work is stimulating and interesting, that they perform useful work (35.2\%) and that they understand development and continuous learning entirely as part of their work $(30.4 \%)$. The most varying answers were to the question of whether their organization offers the option for recognizing excellent results in work or competition. A total of $49.6 \%$ respondents tended toward positive answers, $12.8 \%$ to neutral answers and $37.6 \%$ to negative answers. The results conform to the fact that a mere $43.2 \%$ of respondents inclined to agree that their organization tries to support talented employees. Detailed results for the individual tested assumptions are indicated in the table below.

\begin{tabular}{|c|c|c|c|c|c|c|c|c|}
\hline Statement & 1 & 2 & 3 & 4 & 5 & 6 & 7 & Total \\
\hline A & 19.2 & 33.6 & 20.8 & 4.8 & 8.8 & 8.8 & 4 & 100 \\
\hline B & 34.4 & 36 & 16 & 3.2 & 7.2 & 2.4 & 0.8 & 100 \\
\hline C & 35.2 & 32.8 & 17.6 & 5.6 & 4.8 & 4 & 0 & 100 \\
\hline D & 28 & 29.6 & 19.2 & 11.2 & 4.8 & 4 & 3.2 & 100 \\
\hline E & 35.2 & 32 & 14.4 & 8 & 4.8 & 4 & 1.6 & 100 \\
\hline F & 37.6 & 38.4 & 16.8 & 5.6 & 1.6 & 0 & 0 & 100 \\
\hline G & 20.8 & 20 & 22.4 & 9.6 & 11.2 & 9.6 & 6.4 & 100 \\
\hline H & 31.2 & 38.4 & 15.2 & 8 & 4 & 3.2 & 0 & 100 \\
\hline I & 11.2 & 20 & 18.4 & 12.8 & 11.2 & 14.4 & 12 & 100 \\
\hline J & 23.2 & 41.6 & 11.2 & 14.4 & 4 & 3.2 & 2.4 & 100 \\
\hline K & 29.6 & 33.6 & 17.6 & 9.6 & 4.8 & 3.2 & 1.6 & 100 \\
\hline L & 30.4 & 18.4 & 22.4 & 11.2 & 8.8 & 3.2 & 5.6 & 100 \\
\hline
\end{tabular}

Tab. 2a: Statements of respondents in relative frequencies

\begin{tabular}{|c|c|c|c|c|c|c|c|c|}
\hline Statement & 1 & 2 & 3 & 4 & 5 & 6 & 7 & Total \\
\hline A & 24 & 42 & 26 & 6 & 11 & 11 & 5 & 125 \\
\hline B & 43 & 45 & 20 & 4 & 9 & 3 & 1 & 125 \\
\hline C & 44 & 41 & 22 & 7 & 6 & 5 & 0 & 125 \\
\hline D & 35 & 37 & 24 & 14 & 6 & 5 & 4 & 125 \\
\hline E & 44 & 40 & 18 & 10 & 6 & 5 & 2 & 125 \\
\hline F & 47 & 48 & 21 & 7 & 2 & 0 & 0 & 125 \\
\hline G & 26 & 25 & 28 & 12 & 14 & 12 & 8 & 125 \\
\hline H & 39 & 48 & 19 & 10 & 5 & 4 & 0 & 125 \\
\hline I & 14 & 25 & 23 & 16 & 14 & 18 & 15 & 125 \\
\hline J & 29 & 52 & 14 & 18 & 5 & 4 & 3 & 125 \\
\hline K & 37 & 42 & 22 & 12 & 6 & 4 & 2 & 125 \\
\hline L & 38 & 23 & 28 & 14 & 11 & 4 & 7 & 125 \\
\hline
\end{tabular}

Tab. 2b: Statements of respondents in absolute frequencies

On the basis of an assessment of the data collected it can be stated that most of the respondents inclined to think that their work more or less gives a feeling of personal success, consider assuming accountability for resolving work tasks as an opportunity to gain experience, and are themselves motivated to work on themselves and to deepen their knowledge and obtain new knowledge.

The results of the study can be summarized to state that a development program should be prepared and executed by the organization and monitored by managers which can take into account the individual needs of the individual employees.

Furthermore, factor analysis was made in consequence to correlation matrix which have shown relations between all variables. Regarding overall medium till strong dependences between variables, constructed for the survey for the reason of 
their clear use in the construct, it was expected to find statistically significant factors. Correlation coefficients of variables used for factor analysis were optimally strong to give significant results by Varimax rotation method. As shown in Table 3 and 4 , factor analysis revealed 3 statistically significant factors. To separate final amount of output factors a Kaiser-Guttman rule was employed.

\begin{tabular}{|c|c|c|c|}
\hline Factor & Total variance & $\begin{array}{c}\text { Total \% of } \\
\text { Variance }\end{array}$ & $\begin{array}{c}\text { Cumulative \% of } \\
\text { Variance }\end{array}$ \\
\hline 1 & 5.833 & 48.610 & 48.610 \\
\hline 2 & 1.363 & 11.360 & 59.970 \\
\hline 3 & 1.145 & 9.546 & 69.516 \\
\hline
\end{tabular}

Tab. 3: Variance explained by factors

Such factors were used for further analysis, whose variance was higher than 1.0. This value wa chosen rationally because explanatory factor must have at least equal value as original standardised determinant. Such variables (statements of respondents) were chosen as significant to create resulted factor, whose value was 0.3 and higher (Anderson, 2009). Factors together explain $69.52 \%$ of behaviour of total construct.

\begin{tabular}{|c|c|c|c|}
\hline Variable & Factor 1 & Factor 2 & Factor 3 \\
\hline A & 0.400 & $\mathbf{0 . 7 4 2}$ & -0.098 \\
\hline B & $\mathbf{0 . 8 3 4}$ & 0.196 & 0.153 \\
\hline C & $\mathbf{0 . 7 8 3}$ & 0.364 & 0.180 \\
\hline D & $\mathbf{0 . 7 8 1}$ & 0.396 & 0.144 \\
\hline E & $\mathbf{0 . 7 3 9}$ & 0.401 & 0.249 \\
\hline F & $\mathbf{0 . 5 5 2}$ & -0.246 & $\mathbf{0 . 5 2 3}$ \\
\hline G & 0.378 & $\mathbf{0 . 6 8 4}$ & 0.235 \\
\hline H & 0.264 & 0.087 & $\mathbf{0 . 6 8 4}$ \\
\hline I & 0.088 & $\mathbf{0 . 6 1 8}$ & 0.361 \\
\hline J & 0.225 & 0.253 & $\mathbf{0 . 7 9 8}$ \\
\hline K & -0.042 & $\mathbf{0 . 4 5 6}$ & $\mathbf{0 . 7 1 4}$ \\
\hline L & 0.336 & $\mathbf{0 . 6 8 6}$ & 0.324 \\
\hline \% of variance & $\mathbf{4 8 . 1 6 0}$ & $\mathbf{1 1 . 3 6 0}$ & $\mathbf{9 . 5 4 6}$ \\
\hline Name of the factor & $\begin{array}{c}\text { Knowledge } \\
\text { employee }\end{array}$ & $\begin{array}{c}\text { Talented } \\
\text { employee }\end{array}$ & $\begin{array}{c}\text { Developing } \\
\text { employee }\end{array}$ \\
\hline
\end{tabular}

Tab. 4: Resultant factors by method Varimax

The first factor (Factor 1) describes an employee who is satisfied with its job, working in its area of interest, using gain knowledge, skills and abilities. Such employee is willing to be responsible for its work tasks and search for strategic importance of its job position. He/she sees his/her position as interesting and developing, giving the social status and personal success. Additionally, such employee thinks his/her job supports home organisation and also society. Thus we may summarize that the factor describes a knowledge employee because of its current and still developing knowledge used at work process, interest in job position and organisation and willingness to work for it in the best manner. The name of the first factor therefore is Knowledge employee.

The first factor is also found on the first place by factor analysis as the most significant, which is proved by the highest variance of this factor (5.833). It is the highest variance above all factors found by factor analysis. Together almost half of surveyed employees $(48.16 \%)$ behave in this manner and see their employer as cooperative and good place to be and work.

Factor number 2 revealed different type of employee behaviour. The second type of employees stated they have enough possibilities to be developed and to grow constantly in their organisation; their home organisation supports employee development, education and learning. Additionally, home organisation offers special rewards and awards or appreciation of superior outputs at work; employees in that organisation may compete in different competitions focused on work, projects and other concepts. Employees grouped by Factor 2 are also constantly developed and take part on development program periodically or on regular base. Employees also stated that development, learning and education is part of their job.

Such description evokes talent employees who are part of talent pool or talent program. Described organisational environment is quite superior, supporting talented employees and profiting from their constant development. Total $11.36 \%$ of employees work in described environment and may be considered as talents.

The third factor (Factor 3) revealed constantly developing employee. He/she is characterized by motivation to learn and being educated and developed, he/she is constantly part of development program. Revealed type of employee also takes responsibility and is aware of self-management which is familiar for him/her. Moreover, development of an employee have straight impact on employees work.

Factor 3 therefore describes constantly developing employee in the way his/her job position is being developed. Thus the name of the factor Developing employee. Almost $10 \%$ of respondents work in this kind of organisational culture.

Based on presented results of analyses we found about $70 \%$ of surveyed employees to be really developing by their organisations or at least are motivated to be developed: in the manner of knowledge employee, talent employee or developing employee. Such results seem quite positive, but still there are questions. Basically, $30 \%$ of employees do not use knowledge, talent or development techniques or are not supported in their development by their home organisation, they have no possibility to grow and there are no succession or career plans for them. Based on the results of descriptive statistics, $27 \%$ of employees do not feel any possibility to grow and that may lead to disaffection, loss of production or even to employee turnover. Employees, who miss adequate level of development are usually key and knowledge employees; it is necessary to support their career plans and development to retain them in organisation.

Anyway, 70\% of employees are being educated, going through constant learning, development or talent program seem to be quite a good result. On the other hand, based on other similar researches, just about 20\% of employees (measured in the population) are being developed (Maršíková, Šlaichová, 2014; Linhartová, 2012) or can be named as knowledge workers or talents (Linhartová, 2012). This may occur because only such employees, who are interested in development programme, took part in the survey; the others refused to answer.

As we analysed different size of organisations (small, medium, large), there was a potential of different results according to size of a company, age of respondents etc. We found, similarly as results of other similar surveys or researches (i.e. Benito-Hernandez et al., 2015; Denicolai et al., 2015; Weitlaner, Kohlbacher, 2015; Linhartová, Urbancová, 2012; Urbancová, Linhartová, 2012; Linhartová, Urbancová, 2011), that there is not statistically significant difference. On the other hand, we found that mainly small, micro, and then large multinational organisations use such methods and approaches as talent management, knowledge management and for example mobility management. The results of those surveys revealed that small and micro companies are managed according to modern trends of management to keep 
competitiveness. Also, large international organisations have all those processes internally described and followed according to their foreign management who is used to those methods. Usually, the biggest gap can be found in medium organisations, which still have not incorporated modern practices to use them in praxis and daily processes. Anyway, the sample consists of 125 responses, thus it is possible to provide this analysis as the distribution of responses is appropriate and in accordance with results of other similar surveys.

\section{Conclusion}

Presented paper analysed possibilities of employee development in organisations. Research outcomes identified types of employee development programmes and attitudes of organisational learning. Results describe the main types of employee behaviour during development. Based on presented results, $69.52 \%$ of respondents have an opportunity of being developed or are internally motivated for development. We may also describe possibilities of employee development in Czech organisations as following three approaches (based on results of factor analysis): Knowledge employee management, Talent employee management and Developing employee management. Employees are both self-motivated and self-managed or supported by their home organisation.

Based on presented outputs, we may evaluate possibilities of employee education and development. Firstly, it is employee him/herself, who sees the potential and willing to grow (Factor $1-48 \%$ ). It is a pleasure to work with such employee in organisation. He/she wants to be developed and search for opportunities him/herself inside or outside the organisation and uses his/her knowledge to upgrade his/her work outputs. Secondly, he/she is a part of talent program already running in an organisation (Factor $2-11 \%$ ). Such employee works in line with organisational program and understands its reason. Development of employees in such organisation is smooth and both sides know the reason and necessary steps. Finally, third type of employees (Factor $3-9.5 \%$ ) is searching for development. They are motivated for self-development and try to be constantly part of development program. They are responsible and thus it is easy to educate and develop this type of employee. Organisations which have any one of described type of employee may have competitive advantage in the future labour market.

Besides this study there are several promising avenues for further research. It would be useful to know the impact on employee mobility and total outputs of an organisation. Link between employee behaviour in the revealed 3 types and organisational outputs would be interesting study for research in the future.

A theoretical benefit of this article is the summary of characteristics of talented employees in the organizations studied. A practical benefit of this article is the determination of what options for education and development are preferred by these employees. Organizations can modify their development programs according to the 3 types of employees defined and their attitudes toward development. Given the number of respondents $(n=125)$ the study results can be generalized only to the given sample set. And yet this study in the area of talent management will be repeated on an ongoing basis with the prerequisite of addressing a larger, representative sample of employees.

\section{Acknowledgements}

This contribution is a follow-up to the project of University of
Economics and Management.

\section{References}

Antonacopoulou, E. P. (2000) 'Employee development through self-development in three retail banks', Journal of Personnel Review, vol. 29, no. 4, pp. 491-508.

Anderson, V. (2009) Research Methods in Human Resource Management, London: Chartered Institute of Personnel Development.

Armstrong, M. (2009) Odměňování pracovníků. Praha: Grada Publishing.

Armstrong, M. (2007) Ř́zení lidských zdrojů, Praha: Grada Publishing.

Armstrong, M. (2005) Ř́zení lidských zdrojů, Praha: Grada Publishing.

Bedrnová, E. and Nový, I. (2007) Psychologie a sociologie ř́zení. Praha: Management Press.

Bedrnová, E., Nový I. and Jarošová, E. (2012) Manažerská psychologie a sociologie, Praha: Management Press.

Benito-Hernandez, S., Lopez-Cozar-Navarro, C., PriedeBergamini, T. (2015). 'Examining the relationship between firm size and external advice on legal matters and human resources by family businesses', Journal of Business Economics and Management, vol. 16, no. 3, pp. 483-509.

Bělohlávek, F. (2008) Jak vést a motivovat lidi, Brno: Computer Press.

Colvin, G. (2010) Talent nerozhoduje, Brno: Computer Press.

Constantine, D. (2012) Employers Should Take Responsibility for Employee Development Available at: http://www.evolllution. com/opinions/employers-should-take-responsibility-foremployee-development/.

Champathes, M. R. (2006) 'Coaching for performance improvement: The coach model', Development and Learning in Organizations, vol. 20, no. 2, pp.17-18.

Deibl, M. (2005) Motivace jako nástroj ř́zení, Praha: Linde.

Denicolai, S., Ramusino, E. C., Sotti, F. (2015). 'The impact of intangibles on firm growth', Technology Analysis \& Strategic Management, vol. 27. no. 2, pp. 219-236.

Dvořáková, Z. et al. (2007) Management lidských zdrojů. Praha: C.H.Beck.

Dvořáková, Z. (2004) Slovník pojmů k řizení lidských zdrojů, Praha: C.H. Beck.

Drucker, P. F.(2000) Výzvy managementu pro 21. století, Praha: Management Press.

Edgar, F. and Geare, A. (2005) 'HRM Practice and Employee Attitudes: Different Measures - Different Results', Personnel Review, vol. 34, pp. 534-549.

Folwarczná, I. (2010) Rozvoj a vzdělávání manažerů. Praha: Grada Publishing.

Gannon, J. M. and Maher, A. (2012) 'Developing tomorrow's talent: the case of an undergraduate mentoring programme', Education + Training, vol. 54, no. 6, pp. 440-455.

Georgellis, Y. and Lange, T. (2007) 'Participation in Continuous on-the-job Training and Job Satisfaction: Longitudinal Evidence from the German Labour Market', International Journal of Human Resource Management, vol. 18, pp. 969-985.

Gerbman, R. V. (2000) 'Corporate Universities', HR Magazine, vol. 45, no. 2, pp. 101-106. 
Hameed, A. and Waheed, A. (2011) 'Employee Development and Its Affect on Employee Performance A Conceptual Framework', International Journal of Business and Social Science, vol. 2, no. 13, pp. 224-229.

Hroník, F. (2007) Rozvoj a vzdělávání pracovníki̊, Praha: Grada Publishing.

Kavita, D. and Diksha, G. (2014) 'Study on Training and Development in Public Sector Banks', International Journal of Management and Social Sciences Research, vol. 3, no. 1, pp. $1-5$.

Kocianová, R. (2010) Personální činnosti a metody personální práce, Praha: Grada Publishing.

Koubek, J. (2007) Řízení lidských zdrojů: základy moderní personalistiky, Praha: Management Press.

Lee, C.H. and Bruvold, N. T. (2003) 'Creating Value for Employees: Investment in Employee Development', International Journal of Human Resource Management, vol. 14, pp. 981-1000.

Lipman, V. (2013) Why Employee Development Is Important, Neglected And Can Cost You Talent. Available at: http://www. forbes.com/sites/victorlipman/2013/01/29/why-developmentplanning-is-important-neglected-and-can-cost-you-youngtalent/.

Linhartová, L. (2012) 'Transfer of Employees as a Way of Career Growth', Trends of Economics and Management, vol. 6, no. 10 , pp. 68-76.

Linhartová, L. and Urbancová, H. (2012). Results of analysis of employee mobility: factors affecting knowledge continuity. Acta Universitatis Agriculturae et Silviculturae Mendeleianae Brunensis, vol. 60, no. 4, pp. 235-244.

Linhartová, L. and Urbancová, H. (2011). 'The comparison of the causes of employees' turnover and knowledge continuity ensuring in small and large organisations', Agrarian Perspectives. Praha: Czech University of Life Sciences.

Malátek, V. (2011) Sociálně-psychologické aspekty motivace a rozvoje pracovnikü. Available at: http://www.opf.slu.cz/ aak/2011/04/malatek.pdf.

Maršíková, K. and Šlaichová, E. (2014) 'Investment in training: Productivity and human capital value', In Proceedings of the 8th International Days of Statistics and Economics, Prague: pp. 1016-1026.

Michela, J. L. (2007) 'Understanding employees'reactions on supervisors'influence behaviours', International Journal of Organisational Analysis, vol. 15, no. 4, pp. 322-340.

Muse, L. A. and Stamper, C. L. (2007) 'Perceived Organizational Support: Evidence for a Mediated Association with Work Performance', Journal of Managerial Issues, vol. 19, pp. 517535.

Morongová, A. and Urbancová, H. (2014) 'Talent Management as a Part of Employee Development - Case Study', In 11th International Conference Efficiency and Responsibility in Education, pp. 471-477.

Nel, P., Gerber, P., van Dyk, P., Haasbroek, D., Schultz, H., Sono, T. and Werner, A. (2004) Human resources management, South Africa: Oxford University Press.

Osborne, J. S. (2002) Components of Empowerment and How They Differentially Relate to Employee Job Satisfaction, Organizational Commitment, and Intent to Leave the Job, Peabody College of Vander-bilt University.

PPM Factum (2012) Online šetřenís vybranými zaměstnanci kraju, Available at: http://ceses.cuni.cz/CESES-355-version1technicka_a_zaverecna_zprava_z.pdf.

Robbins, S. P., Odendaal, A. and Roodt, G. (2003) Organizational behavior: Global and Southern African perspectives. South Africa: Pearson Education.

Schmidt, S. W. (2007) 'The Relationship Between Satisfaction with Workplace Training and Overall Job', Human Resource Development Quarterly, vol. 18, no. 4, pp. 481-498.

Stýblo, J. (2008) Management a lidé ve firmě, Praha: Vysoká škola finanční a správní.

Stýblo, J. (2013) Několik poznámek k motivaci - empowerment, engagement. Available at: http://www.ucetnikavarna.cz/archiv/ dokument/doc-d41458v52364-nekolik-poznamek-k-motivaciempowerment-engagement/.

Thomson, R. (2007) Ř́zení lidí: Managing people. Praha: ASPI. Tureckiová, M. (2004) Rízení a rozvoj lidí ve firmách, Praha: Grada Publishing.

Urbancová, H. and Linhartová, L. (2012). 'Knowledge continuity ensuring and elimination of employee turnover in organisations in the Czech Republic'. Ekonomická revue - Central European Review of Economic Issues, vol.15, no. 2, pp. 95-106.

Useem, M. (1993) Company Policies on Education and Training. In Mirvis, P.H. (ed.) Building The Competitive Workforce: Investing In Human Capital For Corporate Success, New York: Wiley.

Veber, J. et al. (2005) Management: základy, prosperita, globalizace, Praha: Management Press.

Veteška, J. and Tureckiová, M. (2008) Vzdělávání a rozvoj podle kompetencí: kompetence $v$ andragogice, pedagogice a řizení. Praha: Univerzita Jana Amose Komenského.

Vodák, J. and Kucharčíková, A. (2011) Efektivní vzdělávání zaměstnanců, Praha: Grada Publishing.

Vnoučková, L. (2014) 'Employee Development in Human Resource Management', In: 8th International Days of Statistics and Economics, pp. 1598-1605.

Vronský, J. (2012) Profesiografie a jeji praktické využití při ř́zení lidských zdrojů v organizaci, Prague: Wolters Kluwer ČR. Weitlaner, D. and Kohlbacher, M. (2015). 'Process management practices: organizational (dis-) similarities', Services Industries Journal, vol. 35, no. 1-2, pp. 44-61. 